\title{
Leadership Talk by the AJC Director of International Jewish Affairs; Personal Representative of the OSCE Chairperson-in-Office on Combating Anti-Semitism
}

Fifteen years have passed since the OSCE held its first conference on antisemitism in June 2003, here in Vienna. It addressed specific matters relevant to antisemitism, including the importance of understanding and defining it, the need for education about Judaism and the Jewish community, and the value of promoting Holocaust education and remembrance.

But the conference also spoke in general and comprehensive ways by offering recommendations. It underscored the obligation for governments to identify and monitor hate crimes, the need to train police and prosecutors, and the need to teach students about religion and religious communities generally.

In that pre-social media era, the conference flagged concerns about the spread of hate on the internet and the responsibility of traditional media to avoid promoting intolerance. ${ }^{1}$

It offered the OSCE as a place for governments to share best practices and to prod its participating States to do more.

Before the conference had come to an end, the German delegation stood up to propose that it host a follow-up conference in Berlin the following year. That conference and the Berlin Declaration that resulted from it were a milestone in efforts by the OSCE to tackle the problem of antisemitism.

In carefully worded language, the conference began a process of defining antisemitism as it relates to Israel. The declaration spoke of antisemitism taking on "new forms and expressions,"2 and it made clear that incidents in Israel and the Middle East could never justify antisemitic attacks.

It spelled out commitments for participating States and for the OSCE's Office for Democratic Institutions and Human Rights (ODIHR), including identifying

1 Cf. "OSCE Conference On Anti-Semitism, Vienna, 19 and 20 June 2003: Consolidated Summary," Organization for Security and Co-operation in Europe, issued July 18, 2003, https://www. osce.org/cio/42394?download=true.

2 "Berlin Declaration, 2004," Organization for Security and Co-operation in Europe, issued April 29, 2004, https://www.osce.org/cio/31432?download=true.

Ә OpenAccess. (c) 2019 Andrew Baker, published by De Gruyter. (cc) BY-NC-ND This work is licensed under the Creative Commons Attribution-NonCommercial-NoDerivatives 4.0 License. 
and monitoring hate crimes and promoting Holocaust education. It led to the creation of a new department in ODIHR focused on promoting tolerance and nondiscrimination.

We must acknowledge that antisemitism is no less a problem today than it was fifteen years ago. But we are better able to understand it, governments are more willing to acknowledge it, and we have more tools at our disposal to address it.

In January of this year, the Italian OSCE Chairmanship organized the Rome International Conference on the Fight against Anti-Semitism. This conference also stressed the value of education, spoke of the need to understand religions and religious differences, and reviewed the progress of governments in monitoring and responding to hate crimes. ${ }^{3}$ However, what made this conference unique was the presenters and discussants themselves, who now have the benefit of real work experience to share.

And today's environment is not the same as it was fifteen years ago.

In 2003, we had not fully appreciated the very real security challenges that Jewish communities faced and the genuine anxiety that many Jews have come to feel in just the public observance of their faith. It has taken lethal attacks and physical harassment to mobilize authorities.

We must acknowledge the complicated and even contradictory forces in our work to combat antisemitism connected to immigration and the politics of immigration. Large numbers of migrants have come from majority Muslim countries in the Middle East and North Africa, where anti-Jewish and anti-Israeli sentiments are commonplace.

We do not know yet that immigration will necessarily mean an increase in antisemitism, but it adds to the challenges of integrating them and to standing concerns about antisemitism in the more established Muslim communities. At the same time, these immigrants themselves are victims of prejudice, and they are being used to fuel the campaigns of right-wing, populist parties. Their support is growing, and these parties and their members are no less antisemitic than they are anti-Muslim.

In the United States, we have seen an increase in antisemitic incidents, including examples that also reveal how Jews still serve as ready targets from all corners of the political spectrum. In 2017, neo-Nazis and white supremacists

3 Cf. "Rome International Conference on the Responsibility of States, Institutions and Individuals in the Fight against Anti-Semitism in the OSCE Area," Organization for Security and Co-operation in Europe, issued January 26, 2018, https://www.osce.org/chairmanship/368061?down load=true. 
railed against Jews in their torchlight parade in Charlottesville. ${ }^{4}$ Meanwhile, progressive groups on college campuses are telling Jewish students who support Israel that they are not welcome to be part of their anti-racist coalitions. ${ }^{5}$ And on some of those same campuses, posters recently appeared claiming that a Jewish conspiracy was behind liberal efforts to derail President Trump's recent Supreme Court nominee.

We face as irrational a mix of antisemitic charges today as we did a century ago, when Jews were blamed for both communism and capitalism.

European Jewish leaders will debate whether antisemitism coming from the right (nationalists, populists, neo-Nazis) or the left (usually as part of an antiZionist agenda) or from still another source (an immigrant population with roots in the Middle East) is the most significant danger at the moment. But there is no disagreement that the problem in all three of these categories has been steadily increasing. ${ }^{6}$

Twenty years ago, we witnessed significant measures being taken in the new democracies of Central and Eastern Europe to confront the legacy of the Holocaust in these countries. It was not easy after a half-century of communist oppression to look critically at the role their fascist-era governments and local citizens played in assisting the Nazis in their genocidal mission. But a process was put in place. National historical commissions provided a critical review of those complicated years. New Holocaust memorials and educational programs were established. Legislation provided for the restitution of former Jewish property. Political leaders came to recognize that it was not appropriate to rehabilitate or pay honor to wartime fascist leaders who were complicit in the murder of Jews, even if they in turn had been persecuted under communism because of their nationalism.

Different countries moved in different ways and at different paces, but the direction was largely positive. We cannot say that today, when many of these same countries are looking to revise and distort the authentic, critical narrative

4 Cf. H. Spencer, S. G. Stolberg, "White Nationalists March on University of Virginia," The New York Times, August 11, 2017, https://www.nytimes.com/2017/08/11/us/white-nationalists-rallycharlottesville-virginia.html.

5 Cf. D. Ziri, “'Massive Drop in US Jewish College Students' Support for Israel',” The Jerusalem Post, June 22, 2017, https://www.jpost.com/American-Politics/Israel-dramatically-losing-supportamong-Jewish-college-students-in-US-497605.

6 FRA's December 2018 survey of Jews in the EU reports that respondents cite as perpetrators of antisemitic incidents those with extreme Muslim views $30 \%$, with left-wing political views $21 \%$, and with right-wing political views 13\%. European Union Agency for Fundamental Rights, Experiences and Perceptions of Antisemitism: Second Survey on Discrimination and Hate Crime Against Jews in the EU (Luxembourg: Publications Office of the European Union, 2018), 13. 
of the Holocaust and the role of wartime leaders. Twenty years ago, we might have excused this as a matter of naiveté or ignorance. Today, they know better, but do it all the same.

For Jewish communities comprised primarily of Holocaust survivors and their descendants, this is much more than a question of history; it goes to their very sense of belonging.

There has been real progress in employing a comprehensive definition of antisemitism. That first Working Definition, issued by the European Monitoring Centre on Racism and Xenophobia (EUMC) in 2005, was adopted by the thirtyone-nation International Holocaust Remembrance Alliance (IHRA) in 2016. It has been recommended for use by the European Parliament and the OSCE Parliamentary Assembly, and a growing number of countries have formally adopted it. ${ }^{7}$ The Chief Rabbi of the United Kingdom and the Archbishop of Canterbury jointly endorsed the definition with its full list of examples and without any modifications, a very public condemnation of antisemitism in the political arena. $^{8}$

On occasion, we look at the problem of antisemitism through the broader prism of protecting the freedom of religion and belief. Let me then illustrate how adhering to these principles can also direct our work.

We need to recognize that Jewish security fears directly impact the ability to worship freely and to engage in related communal activity. Additionally, political efforts ostensibly in the name of protecting children or for the humane treatment of animals threatens the freedom to conduct certain religious practices that are elemental to Judaism.

As both FRA surveys indicate, one third of the Jewish population avoids wearing religiously-identifying symbols in public or even attending Jewish events for fear of being harassed or attacked. ${ }^{9}$ Synagogues, schools, and other communal buildings require special protection and often stringent security mea-

7 Until July 2018, the Working Definition of Antisemitism has been adopted and endorsed by the United Kingdom (December 12, 2016), Israel (January 22, 2017), City of London (February 8, 2017), Austria (April 25, 2017), Scotland (April 27, 2017), Romania (May 25, 2017), Germany (September 20, 2017), Bulgaria (October 18, 2017), Lithuania (January 24, 2017), and the Republic of Macedonia (March 6, 2018). Cf. "Working Definition of Antisemitism," International Holocaust Remembrance Alliance, issued May 26, 2016, https://www.holocaustremembrance.com/newsarchive/working-definition-antisemitism.

8 Cf. N.N. "Church of England's Bishops Adopt Full International Holocaust Remembrance Alliance Definition of Anti-Semitism," Jewish Telegraphic Agency, September 13, 2018, https://www. jta.org/2018/09/13/global/church-englands-bishops-adopt-full-international-holocaust-remem brance-alliance-definition-anti-semitism.

9 Cf. FRA, Experiences and Perceptions of Antisemitism, 38. 
sures must be employed. Who can deny that this adversely constrains basic religious freedoms?

There are ongoing efforts in several European states to restrict or outright ban the practice of infant (and child) circumcision. ${ }^{10}$ Even when Jews were subject to many antisemitic restrictions in pre-modern Europe, no one sought to restrict this practice, whose origins can be traced to the first book of the Bible. Even granting that the proponents of these efforts are only concerned with the well-being of children and have no intention of promoting antisemitism, the public and social media discourse that accompanies their activities is frequently and overtly antisemitic. In a similar fashion, a growing number of European states have banned the practice of religious (kosher) slaughter. ${ }^{11}$ Together, these efforts, if successful, seriously threaten the future of Jewish life in Europe.

In conclusion, as we gather here in Vienna to marshal our collective efforts to put "an end to antisemitism," we have new tools, increasing government com-

10 Cf. for example H. Sherwood, "Iceland Law to Outlaw Male Circumcision Sparks Row over Religious Freedom,” The Guardian, February 18, 2018, https://www.theguardian.com/society/ 2018/feb/18/iceland-ban-male-circumcision-first-european-country; M. Busby, "Danish Parliament to Consider Becoming First Country to Ban Circumcision of boys," Independent Minds, June 3, 2018, https://www.independent.co.uk/news/world/europe/denmark-boyhood-circum cision-petition-danish-parliament-debate-a8381366.html.

11 Slovenia, Denmark, and Poland were among the first European Countries to re-evaluate ritual slaughter. Already in 2012, Slovenia's Animal Welfare Act was amended to add provisions banning all ritual slaughter of animals, thus making Slovenia the first country in the European Union to fully ban any ritual slaughter of animals, both kosher and halal. Cf. "Zakon o Zaščiti Živali [Animal Welfare Act]”, issued November 28, 1999, amended 2012, http://extwprlegs1.fao.org/docs/ html/slv 101698.htm. Following this decision, Poland's Constitutional Court effectively banned religious slaughter following protests by animal welfare groups. However, religious slaughter continued in practice in Poland and led to the ban being overturned in 2014 on religious freedom grounds. Cf. N.N., "Polish Ban on Kosher Slaughter of Animals is Overturned,” BBC News, December 10, 2014, https://www.bbc.com/news/world-europe-30412551.

Denmark too banned ritual kosher and halal slaughter for reasons of animal welfare in 2014. Cf. A. Withnall, "Denmark Bans Kosher and Halal Slaughter as Minister Says 'Animal Rights Come before Religion',” Independent Minds, February 18, 2014, https://www.independent.co.uk/news/ world/europe/denmark-bans-halal-and-kosher-slaughter-as-minister-says-animal-rights-comebefore-religion-9135580.html. .

Until today, the discussions and legal decisions of countries such as Denmark and Poland have given continuous rise to re-evaluations of and attempts to ban kosher and halal slaughter in other European countries too. Currently, Belgium plans on a complete ban of ritual slaughter to be executed in late 2018 or early 2019. Cf. "Legislation on Religious Slaughter: Factsheet," DIALREL: Encouraging Dialogue on Issues of Religious Slaughter, accessed July 28, 2018, http:// www.dialrel.eu/images/factsheet-legislation.pdf. 
mitments, and greater communal resolve to take up the fight, but the problem remains complex and intractable.

Rabbi Andrew Baker is AJC Director of International Jewish Affairs. In 2009, he was appointed Personal Representative on Combating Anti-Semitism of the Chairperson-in-Office of the Organization for Security and Cooperation in Europe (OSCE) and continues to serve in this position. He is an officer of the Jewish Claims Conference and has served on restitution and historical commissions in the Czech Republic, Lithuania, Romania and Slovakia. In recognition of his work in Europe he was decorated by the Presidents of Germany, Lithuania, Latvia and Romania. He is a past President of the Interfaith Conference of Washington, a former Commissioner of the District of Columbia Human Rights Commission, a past President of the Washington Board of Rabbis and a former chaplain at San Quentin Prison.

\section{Bibliography}

Busby, Mattha. "Danish Parliament to Consider Becoming First Country to Ban Circumcision of Boys.” Independent Minds, June 3, 2018. https://www.independent.co.uk/news/ world/europe/denmark-boyhood-circumcision-petition-danish-parliament-debatea8381366.html.

DIALREL: Encouraging Dialogue on Issues of Religious Slaughter. "Legislation on Religious Slaughter: Factsheet.” Accessed July 28, 2018. http://www.dialrel.eu/images/factsheetlegislation.pdf.

European Union Agency for Fundamental Rights, Experiences and Perceptions of Antisemitism: Second Survey on Discrimination and Hate Crime against Jews in the EU. Luxembourg: Publications Office of the European Union, 2018.

International Holocaust Remembrance Alliance. "Working Definition of Antisemitism." Issued May 26, 2016. https://www.holocaustremembrance.com/news-archive/working-defi nition-antisemitism.

N.N. "Church of England's Bishops Adopt Full International Holocaust Remembrance Alliance Definition of Anti-Semitism." Jewish Telegraphic Agency, September 13, 2018. https:// www.jta.org/2018/09/13/global/church-englands-bishops-adopt-full-international-hol ocaust-remembrance-alliance-definition-anti-semitism.

N.N. "Polish Ban on Kosher Slaughter of Animals is Overturned." BBC News, December 10, 2014. https://www.bbc.com/news/world-europe-30412551.

Organization for Security and Co-operation in Europe. "OSCE Conference On Anti-Semitism, Vienna, 19 and 20 June 2003: Consolidated Summary.” Issued July 18, 2003. https:// www.osce.org/cio/42394?download=true.

Organization for Security and Co-operation in Europe. "Berlin Declaration, 2004." Issued April 29, 2004. https://www.osce.org/cio/31432?download=true.

Organization for Security and Co-operation in Europe. "Rome International Conference on the Responsibility of States, Institutions and Individuals in the Fight against Anti-Semitism 
in the OSCE Area." Issued January 26, 2018, https://www.osce.org/chairmanship/ 368061?download=true.

Sherwood, Harriet. "Iceland Law to Outlaw Male Circumcision Sparks Row over Religious Freedom." The Guardian, February 18, 2018. https://www.theguardian.com/society/ 2018/feb/18/iceland-ban-male-circumcision-first-european-country.

Spencer, Hawes, and Sheryl Gay Stolberg. "White Nationalists March on University of Virginia.” The New York Times, August 11, 2017. https://www.nytimes.com/2017/08/11/ us/white-nationalists-rally-charlottesville-virginia.html.

Withnall, Adam. "Denmark Bans Kosher and Halal Slaughter as Minister Says 'Animal Rights Come before Religion'." Independent Minds, February 18, 2014. https://www.in dependent.co.uk/news/world/europe/denmark-bans-halal-and-kosher-slaughter-as-minis ter-says-animal-rights-come-before-religion-9135580.html.

“Zakon o Zaščiti Živali [Animal Welfare Act].” Issued November 28, 1999, amended 2012. http://extwprlegs1.fao.org/docs/ html/slv101698.htm.

Ziri, David. “'Massive Drop in US Jewish College Students' Support for Israel'.” The Jerusalem Post, June 22, 2017. https://www.jpost.com/American-Politics/Israel-dramatically-losingsupport-among-Jewish-college-students-in-US-497605. 
